\title{
Parenting Self Efficacy pada Orang Tua dengan Tuna Netra
}

\author{
Mafaza $^{1 *}$, Hafiz Alfara ${ }^{1}$, Nila Anggrainy ${ }^{1}$ \\ 1Prodi Psikologi Fakultas Kedokteran Universitas Andalas \\ *azamafaza@gmail.com
}

\begin{abstract}
This research aims to explore significant description and factors that influence parenting self efficacy toward blind parents with middle childhood children. This research basically applies phenomenology qualitative method. The subject of this research focuses on two couples of blind parents who live with their middle childhood children. The data collection is conducted by applying the interview and observation. All responses were analysed with Van Kaam phenomenology method which has been modified by Moustakas (1994). Parenting self efficacy of the four informant shows great value on domain nurturance, however it shows less value on domains of discipline and recreation. There are various factors that affect parenting self efficacy on these subjects, such as limitation of eyesight, childhood experience, culture and community, experience with children, cognitive level, sociomarital support, and busy hours. Besides, number of children, economy, and children' severe disease can also be influential factors of parenting self efficacy.
\end{abstract}

Keywords: blind, middle childhood children, parenting self efficacy

\begin{abstract}
Abstrak. Penelitian ini bertujuan untuk mengetahui gambaran dan faktor-faktor yang mempengaruhi parenting self efficacy pada orang tua tunanetra yang memiliki anak usia kanak-kanak madya. Metode penelitian yang digunakan adalah metode kualitatif fenomenologi. Informan penelitian ini adalah dua pasangan tunanetra yang memiliki anak usia kanak-kanak madya. Teknik pengambilan sampel yang digunakan adalah purposive sampling, sedangkan teknik pengumpulan data adalah wawancara dan observasi. Prosedur analisis data yang digunakan adalalah metode fenomenologi. Hasil penelitian ini menunjukkan bahwa keempat orang tua tunanetra memiliki keyakinan yang lebih ketika melaksanakan pengasuhan pada domain nurturance. Namun, orang tua tunanetra cenderung merasa tidak yakin bahwa mereka mampu melaksanakan pengasuhan pada domain disiplin dan rekreasi. Faktor yang mempengaruhi parenting self efficacy informan juga berbeda-beda, seperti keterbatasan penglihatan, pengalaman masa kecil, budaya dan komunitas, pengalaman dengan anak-anak, tingkat kesiapan kognitif, dukungan sociomarital, serta kesibukan bekerja. Selain itu, jumlah anak, faktor ekonomi, dan keparahan penyakit anak juga berpengaruh.
\end{abstract}

Kata kunci: anak usia kanak-kanak madya, parenting self efficacy, tunanetra

Orang tua tunanetra memiliki tantangan pengasuhan melebihi orang tua normal lainnya, terutama dalam menjalankan tugas pengasuhan pada anak usia kanak-kanak madya. Sebagian besar tugas pengasuhan pada masa tersebut membutuhkan kemampuan visual dan mobilitas yang merupakan hambatan bagi 
orang tua tunanetra (Hallahan \& Kauffman, 1988), seperti mengawasi, memonitor, membantu mengerjakan tugas sekolah, dan aktif dalam organisasi sekolah. Selain itu, pada masa tersebut anak mulai memasuki dunia yang lebih luas. Hal itu secara tidak langsung memberikan tuntutan pada orang tua tunanetra untuk mampu menguasai berbagai keterampilan dan pengetahuan, seperti dalam bidang akademik dan sosial.

Hasil wawancara yang dilakukan pada beberapa orang tua tunanetra yang memiliki anak usia 5 sampai dengan 12 tahun menunjukkan bahwa mereka mengalami kesulitan dalam menjalankan parenting task, menegakkan disiplin, serta memfasilitasi anak dalam bidang akademik. Selain itu, mereka membutuhkan waktu, tenaga, dan biaya yang lebih untuk melaksanakan pengasuhan dibandingkan dengan orang tua normal. Orang tua tunanetra juga mengungkapkan bahwa pengasuhan yang mereka lakukan tidak lepas dari stigma dan sindiran dari masyarakat.

Berbagai keterbatasan dan kesulitan tersebut mengarah pada perasaan ragu akan kemampuannya untuk berperan sebagai orang tua. Mereka merasa tidak yakin dapat melaksanakan tugas pengasuhan dan menyediakan berbagai kebutuhan anak. Padahal, untuk mengoptimalkan kualitas pengasuhan, orang tua harus dapat meyakini kemampuan mereka. Keyakinan dalam melaksanakan pengasuhan sering disebut dengan parenting self efficacy. Coleman dan Karraker (2000) mendefinisikan parenting self efficacy sebagai penilaian diri atau persepsi orang tua terhadap kemampuan mereka dalam mempengaruhi perilaku dan perkembangan anak-anak mereka secara positif.

Sebagaimana yang ditunjukkan oleh hasil penelitian sebelumnya bahwa parenting self efficacy yang tinggi dapat memprediksi responsivitas orang tua untuk memenuhi kebutuhan anak, keterlibatan orang tua dalam pengasuhan secara langsung, serta strategi coping orang tua yang aktif. Sebaliknya, parenting self efficacy yang rendah berhubungan dengan depresi dan perasaan tidak berdaya pada orang tua, masalah perilaku pada anak, dan bentuk coping yang pasif dalam pengasuhan (Coleman \& Karraker, 2005). Oleh karena itu, parenting self efficacy merupakan suatu kompetensi yang sangat penting bagi orang tua tunanetra untuk membangun kompetensi diri terhadap tantangan yang lebih beragam.

Coleman dan Karraker (2000) mengembangkan lima domain parenting self efficacy yang disesuaikan dengan tugas pengasuhan orang tua pada tahap perkembangan anak usia kanak-kanak madya, yaitu (1) Domain disiplin, yang mengacu pada keyakinan akan kemampuan diri orang tua dalam menangani hal-hal yang terkait dengan disiplin, seperti dalam menegakkan aturan dan memperbaiki perilaku anak dengan menggunakan teknik yang tepat; Domain prestasi (achievement) mencakup keyakinan orang tua akan kemampuannya melaksanakan tugas-tugas pengasuhan terkait prestasi akademis anak, seperti dalam menyediakan bahan bacaan sebagai stimulasi; (3) Domain rekreasi adalah keyakinan orang tua untuk memfasilitasi 
kegiatan rekreasi, dengan menyediakan berbagai kesempatan untuk berekreasi, menyediakan ruang fisik untuk bermain, serta mengembangkan kemampuan sosial anak; (4) Domain nurturance merupakan keyakinan orang tua akan kemampuannya memberikan dukungan emosional dan mendorong perkembangan emosi anak. Terakhir (5) Domain kesehatan, merupakan keyakinan orang tua dalam menjalankan tugasnya menjaga kesehatan anak.

Coleman dan Karraker (2005) juga menguraikan beberapa faktor yang dapat memberikan pengaruh spesifik terhadap pengembangan parenting self efficacy. Faktor tersebut berasal dari orang tua, seperti pengalaman masa kecilnya, pengalamannya dengan anak-anak, serta kesiapannya menjadi orang tua. Ketika mereka memiliki pengalaman masa kecil yang positif, sering secara langsung terlibat dalam pengasuhan anak, dan memiliki wawasan yang luas mengenai pengasuhan, maka akan meningkatkan keyakinan diri mereka selama melaksanakan pengasuhan. Selanjutnya, faktor yang berasal dari luar diri orang tua, seperti dukungan dari pasangan dan juga komunitas di sekitar tempat tinggal. Hal tersebut dapat mempengaruhi perkembangan self efficacy beliefs melalui mekanisme persuasi sosial atau feedback dalam menjalani proses parenting.

Penelitian mengenai parenting self efficacy yang menjadikan orang tua tunanetra sebagai subjeknya masih sangat terbatas. Penelitian sebelumnya yang telah dilakukan adalah mengenai parenting self efficacy dalam kaitannya dengan perilaku pengasuhan pada orang tua tunarungu dengan anak berpendengaran normal (Antawati \& Murdiyani, 2013). Hasil penelitian ini mengungkapkan bahwa parenting self efficacy orang tua tunarungu yang memiliki anak berpendengaran normal berada pada kategori sedang. Parenting self efficacy orang tua tunarungu ini dipengaruhi oleh keterbatasan yang mereka miliki dan ketersedian dukungan sosial.

Penelitian terkait lainnya adalah mengenai parenting pada orang tua tunanetra (Kef \& Hatzmann, 2011). Hasil penelitian tersebut menunjukkan bahwa orang tua tunanetra memiliki ekspektasi yang lebih rendah untuk menjadi orang tua dibandingkan dengan orang tua normal. Selain itu, orang tua tunanetra juga memiliki parenting self efficacy yang sedikit lebih rendah dibandingkan dengan orang tua normal.

Orang tua tunanetra cenderung mengalami kesulitan dalam menjalankan peran dan fungsinya sebagai orang tua. Mereka juga dihadapkan dengan stigma dan sindiran dari masyarakat. Oleh karena itu, orang tua perlu memiliki parenting self efficacy untuk tetap bisa menjalankan pengasuhan yang optimal. Berdasarkan fenomena yang telah diuraikan sebelumnya dan masih sedikitnya penelitian mengenai parenting self efficacy pada orang tua tunanetra dengan anak usia kanak-kanak madya, maka penelitian ini penting untuk dilakukan. Penelitian ini bertujuan untuk mengetahui gambaran dan faktor-faktor yang mempengaruhi parenting self efficacy pada orang tua tunanetra yang memiliki anak usia kanak-kanak madya. 
Penelitian ini diharapkan dapat memberikan informasi tentang parenting self efficacy orang tua tunanetra dalam menjalankan tugas pengasuhan sehingga dapat digunakan untuk mengatasi berbagai permasalahan yang timbul akibat ketidakyakinan diri orang tua tersebut dalam menjalankan pengasuhan.

\section{Metode}

Penelitian ini menggunakan metode kualitatif dengan pendekatan fenomenologis. Informan penelitian ini adalah orang tua tunanetra, yaitu dua pasangan yang memiliki keterbatasan penglihatan. Kedua pasangan tersebut berusia 36-42 tahun dan memiliki pekerjaan sebagai tukang pijat. Mereka memiliki anak dalam tahap perkembangan kanak-kanak madya, yaitu pada usia 5 sampai dengan 12 tahun. Penelitian ini dilakukan di Kota Padang. Untuk menguji keabsahan data maka dilakukan teknik triangulasi (Moleong, 2007), yaitu triangulasi data dengan cara mewawancarai significant other, serta triangulasi metode dengan menggunakan beberapa metode penelitian, yaitu wawancara sebagai metode utama dan observasi sebagai metode pendukung. Prosedur analisis data yang digunakan merujuk pada metode analisis data fenomenologi Van Kaam yang telah dimodifikasi oleh Moustakas (1994), yaitu: mencatat ekspresi yang relevan dan melakukan pengelompokan awal, mereduksi dan mengeliminasi eksepresi tersebut, membuat klaster dan menulisakan tema pada ekspresi yang konsisten, memvalidasi ekspresi dan tema tersebut, menyusun deskripsi tekstural individu, menyusun deskripsi struktural individu, dan menggabungkan ekspresi tekstural dan struktural.

\section{Hasil}

Hasil penelitian ini menunjukkan bahwa orang tua tunanetra merasa mampu untuk memberikan dukungan emosional dan kasih sayang bagi anak-anak mereka. Pada informan satu, tiga, dan empat, keyakinan bahwa mereka bisa memberikan kasih sayang yang cukup kepada anak juga ditunjukkan melalui ucapan dan juga perbuatan, seperti mencium, memeluk, dan membelai anak. Akan tetapi,informan dua merasa tidak yakin bahwa dirinya mampu melaksanakan pengasuhan pada domain nurturance, sehingga ucapan dan perbuatan yang ditunjukkan oleh informan satu, tiga, dan empat tidak terlihat pada informan dua.

Lebih lanjut, anak-anak dari orang tua tunanetra tersebut pernah menunjukkan perasaan sedih dan malu atas keterbatasan orang tua mereka. Hal ini disebabkan oleh hinaan dan ejekan dari teman-teman sebaya mereka. Keempat informan telah memberikan penjelasan kepada anak mereka terkait kondisi keterbatasan yang dialami. Informan satu, tiga, dan empat merasa mampu untuk memahami perasaan dan emosi yang ditunjukkan oleh anak. Mereka juga merasa mampu untuk memberikan dukungan secara emosional atas permasalahan yang dihadapi oleh anak. Oleh sebab itu, anak dapat menerima keadaan orang tua mereka dengan baik dan tidak lagi menunjukkan perasaan negatif terkait kondisi keterbatasan penglihatan 
tersebut.

Selanjutnya adalah domain prestasi dari parenting self efficacy orang tua tunanetra. Hasil penelitian menunjukkan bahwa informan satu dan dua merasa tidak yakin bahwa mereka bisa membantu anak ketika belajar. Mereka juga tidak yakin bisa memfasilitasi berbagai kebutuhan anak dalam bidang pendidikan. Seperti yang disampaikan oleh informan satu:

"Sulit, sebenarnya karena saya tidak pernah mempelajarinya. Kemampuan saya terbatas dalam mendidik dia dalam pelajaran apapun. Jadi terkait masalah belajar ini, saya tidak bisa membantu anak terlalu banyak."

Berbeda dengan informan satu dan dua, informan tiga dan empat merasa yakin dirinya bisa membantu dan menunjang keberhasilan dan prestasi anak di sekolah. Hal tersebut terlihat dari banyaknya fasilitas belajar yang terdapat di rumah informan, serta bagaimana informan ikut serta menemani dan membimbing anak ketika mengerjakan pekerjaan rumah. Kedua informan juga terlibat aktif dalam mengontrol perkembangan akademis anak di sekolah. Seperti yang disampaikan oleh informan empat:

"Di dalam pendidikan Insyallah saya penuhi semua. Yang penting cukup semuanya, selalu saya usahakan supaya dia berhasil. Setiap hari saya tanyakan kepadanya. Apakah ada PR atau ada nilai yang keluar? Itu selalu saya tanyakan. Saya pantau selalu. Apakah turun atau naik Jadi insyaallah sudah bisa. Nilainya tidak ada yang rendah juga."
Pada domain kesehatan, informan satu dan dua merasa tidak yakin bisa menjaga kesehatan anaknya. Hal ini ditunjukkan melalui perlakuan kedua informan pada anaknya yang sakit parah. Setalah melakukan berbagai upaya tetapi merasa tidak berhasil, informan satu dan dua tidak lagi mengupayakan pengobatan untuk anaknya tersebut. Selain itu, mereka juga tidak yakin bahwa mereka bisa memberikan gizi dan nutrisi yang cukup bagi anak. Selama ini mereka tidak pernah memperhatikan gizi dan nutrisi yang dikonsumsi oleh anak.

Sebaliknya, informan tiga dan empat merasa yakin bahwa mereka bisa menjaga kesehatan anaknya. Mereka juga merasa mampu untuk menyediakan berbagai asupan gizi untuk anak, seperti menyediakan sayuran, telur, dan susu, serta mengatur jadwal makan anak dengan teratur. Jarangnya anak terkena penyakit dianggap oleh kedua informan sebagai pembuktian kemampuan mereka dalam menjaga kesehatan anak. Seperti yang disampaikan oleh informan tiga:

"Makan selalu saya cukupi. Kalau sakit langsung saya cari cara untuk mengobatnya. Langsung diobati. Kalau demam, dikompres dulu, jika tidak turun panasnya maka saya beli obat, saya berikan minuman yang tawar, kalau tetap tidak turun panasnya, dibawa ke bidan. Makanya anak ini tidak pernah sakit yang terlalu serius."

Sementara itu, hasil penelitian menunjukkan bahwa domain disiplin adalah domain pengasuhan yang paling bermasalah pada setiap informan. Informan satu, dua, dan empat merasa tidak yakin 
bahwa mereka dapat menerapkan disiplin kepada anak. Mereka juga merasa tidak mampu untuk mengoreksi perilaku anak yang tidak tepat. Informan dua merasa paling tidak yakin dalam menjalankan tugasnya pada domain disipilin. Ia bahkan sudah pasrah dan cenderung mengabaikan perilaku anaknya yang tidak sesuai dengan aturan:

"Saya tidak mengerti harus bagaimana lagi, anak ini nakal, saya memberitahunya tapi dia tidak berubah. Saya sampaikan seperti ini, namun dia tetap sesuka hatinya saja. Ya sudah, saya biarkan saja."

Informan satu, dua, tiga, dan empat juga menunjukkan ketidakyakinan dalam memberikan anak kesempatan melakukan berbagai kegiatan rekreasi. Mereka hampir tidak pernah melakukan kegiatan rekreasi bersama anak. Selain itu, informan satu, dua, dan empat juga tidak yakin bahwa mereka bisa terlibat untuk bermain bersama anak. Mereka hampir tidak pernah terlibat secara langsung untuk bermain bersama anak. Seperti yang disampaikan oleh informan empat:

"Maklum saja, orang yang seperti saya ini, orang yang tidak bisa melihat. Tidak bisa kemana-mana untuk pergi rekreasi. Bagaimana caranya saat sampai di tempat rekreasi nanti. Saya tidak bisa mengawasinya. Itu yang saya ragukan. Kalau di jalan nantinya terjadi apa-apa, maklum lah zaman sekarang ini."

Berdasarkan uraian di atas, orang tua tunanetra memiliki keyakinan yang berbeda-beda dalam menjalankan parenting task mereka. Akan tetapi, secara umum mereka merasa mampu untuk menjalankan pengasuhan pada domain nurturance. Hal ini juga ditunjukkan dari berbagai tindakan mereka dalam memberikan kehangatan secara emosional dan juga mendorong perkembangan emosi anak. Sebaliknya, perasaan tidak yakin muncul pada domain disiplin dan rekreasi. Pada kedua domain tersebut orang tua mengalami berbagai hambatan sehingga cenderung kesulitan menjalankan tugas-tugas pengasuhannya .

Lebih lanjut, faktor-faktor yang dapat mempengaruhi parenting self efficacy orang tua tunanetra yang ditemukan pada penelitian ini adalah sebagai berikut: Pertama, pengalaman masa kecil orang tua tunanetra. Hal itu ditunjukkan oleh informan satu, tiga, dan empat yang semasa kecil mendapatkan perlakuan yang baik dari keluarga mereka. Mereka merasa yakin dapat menjalankan pengasuhan di bidang nurturance. Informan dua yang mengungkapkan bahwa dirinya dianggap sebagai beban oleh orang tuanya dan dikucilkan oleh saudara-saudaranya, merasa tidak yakin dapat menunjukkan rasa sayangnya kepada anak.

Kedua, budaya dan komunitas sekitar tempat tinggal juga memberikan pengaruh terhadap keyakinan diri orang tua tunanetra. Keempat informan menyatakan bahwa keluarga dan masyarakat masih meragukan kemampuan mereka dalam melakukan pengasuhan. Beberapa pihak bahkan pernah meminta hak asuh dari anak keempat informan tersebut karena merasa informan tidak mampu menjalankan tugas pengasuhannya. Selain itu, komunitas di sekitar tempat tinggal mereka juga tidak memberikan informasi yang berkaitan dengan nilai-nilai pengasuhan serta saran- 
saran mengenai perawatan dan perkembangan anak.

Ketiga, pengalaman informan dengan anak-anak. Informan satu dan dua menyatakan bahwa sebelumnya mereka tidak pernah terlibat mengasuh anak-anak sehingga mereka merasa tidak yakin dengan cara yang harus digunakan dalam mengasuh anak. Akan tetapi, informan tiga dan empat sudah sering terlibat mengasuh anak-anak sebelumnya sehingga mereka merasa lebih yakin dalam melakukan tugas-tugas pengasuhan.

Keempat, kesiapan kognitif dan perilaku dari orang tua tunanetra. Semua informan menyatakan bahwa mereka memiliki pengetahuan yang terbatas terkait pengasuhan. Oleh karena itu, mereka sering merasa ragu dalam menjalankan pengasuhan, seperti merasa tidak mampu untuk mendisiplinkan anak dengan teknik yang tepat.

Kelima, dukungan sociomarital juga merupakan faktor penting yang dapat mempengaruhi parenting self efficacy. Hal itu dapat dilihat dari informan satu yang merasa tidak mampu membenarkan perilaku anaknya yang salah karena tidak mendapatkan dukungan dari pasangannya. Sebaliknya, informan tiga dan empat yang saling memberikan dukungan dalam melaksanakan pengasuhan anak, mengungkapkan bahwa keterlibatan pasangannya dalam pengasuhan membuat mereka merasa yakin dapat menunjang perkembangan akademik anak.

Selain kelima faktor yang sebelumnya telah diuraikan oleh Coleman dan Karraker (2005) tersebut, hasil penelitian ini juga menunjukkan bahwa pemaknaan orang tua terhadap keterbatasan penglihatan mereka, kondisi ekonomi, kesibukan bekerja, jumlah anak, serta tingkat keparahan penyakit anak juga merupakan faktor-faktor yang dapat mempengaruhi parenting self efficacy orang tua tunanetra.

\section{Diskusi}

Orang tua tunanetra dihadapkan dengan berbagai tantangan pada saat melaksanakan pengasuhan. Salah satu kompetensi yang paling penting untuk dimiliki oleh orang tua tunanetra yang memiliki anak usia kanak-kanak madya adalah parenting self efficacy. Penelitian ini menunjukkan bahwa orang tua tuna netra merasa mampu untuk memberikan dukungan emosional dan kasih sayang bagi anak-anak mereka. Mereka yakin bahwa mereka mampu membantu anak untuk menghadapi berbagai permasalahan. Anak dari orang tua tunanetra menunjukkan perasaan sedih dan malu terhadap keterbatasan fisik yang dialami oleh orang tua mereka. Hal itu sejalan dengan pernyataan Rogers (2006) bahwa memasuki usia kanak-kanak madya, anak dari orang tua tunanetra mulai menyadari kondisi orang tuanya yang berbeda dari orang tua lain. Mereka juga rentan terhadap ejekan dari teman-teman. Oleh karena itu, orang tua perlu memberikan penjelasan kepada anak terkait keterbatasan mereka. Dalam hal ini, orang tua tunanetra merasa yakin dapat memahami perasaan anak, memberikan dukungan emosional, serta memberikan penjelasan dan jalan keluar bagi anak. Sehingga, anak tidak lagi merasa sedih dan dapat menerima kondisi kedua orang tua mereka. 
Keyakinan yang dirasakan informan satu, tiga, dan empat dipengaruhi oleh faktor pengalaman masa kecil mereka yang positif, dimana mereka diperlakuan dengan baik oleh keluarga. Sebaliknya, ketidakyakinan yang ditunjukkan oleh informan dua dipengaruhi oleh diskriminasi yang dirasakannya di dalam keluarga semasa kecil. Ia merasakan bahwa dirinya tidak pernah disayangi secara tulus, serta diperlakukan secara berbeda oleh orang tuanya dan juga saudara-saudaranya. Informan merasa tidak mampu menunjukkan afeksi dan juga kehangatan emosional karena ia tidak pernah mendapatkannya sebelumnya. Perilaku pengasuhan yang negatif pada waktu kecil tersebutlah yang kemudian mempengaruhi keyakinan dirinya sebagai orang tua dalam melaksanakan pengasuhan.

Hal ini sejalan dengan hasil dari beberapa penelitian sebelumnya yang menunjukkan bahwa orang tua dengan pengalaman masa kecil yang lebih positif, memiliki tingkat parenting self efficacy yang lebih tinggi (Colleman \& Karraker, 1997; Leerkes \& Crockenberg, 2002; Suzuki, Holloway, Yamamoto, Mindnich, 2009). Pengalaman masa kecil yang positif tersebut merupakan gambaran dari perlakuan orang tua mereka yang affectionate, sensitif, responsif, menerima, dan mendukung. Sedangkan, anak yang mengalami konflik dengan orang tuanya di masa kecil dan merasa tidak diterima, ditemukan memiliki rasa percaya diri yang rendah dan memunculkan rasa ketidakpercayaan terhadap orang lain (Hong \& Park, 2012). Oleh karena itu, pengalaman waktu kecil, baik positif atau pun negatif, dapat mempengaruhi bagaimana perkembangan kemampuan seseorang dalam menjalankan nurturance secara efektif.

Pengalaman masa kecil sebagai faktor yang dapat mempengaruhi parenting self efficacy dapat dijelaskan melalui teori internal working model (Bowlby, 1980) yang menyatakan bahwa hubungan kelekatan antara anak dengan orang tuanya dimasa kecil akan mempengaruhi bagaimana mereka berpikir dan berperilaku di masa akan datang. Ketika seseorang mengiterpretasikan pengalaman secara terus menerus, maka secara otomatis atau tanpa disadari juga akan mengembangkan model kognitif untuk menghadapi situasi yang serupa, dalam hal ini terkait dengan anak mereka setelah mereka menjadi orang tua. Selain itu, Bandura (1989) juga menjelaskan hal ini sebagai pengalaman vicarious yang berasal dari hasil observasi terhadap perilaku orang lain. Ketika seseorang menyaksikan bagaimana orang tuanya berhasil dalam mendidik mereka, maka terbentuklah model perilaku pengasuhan yang dapat mereka terapkan pada anak mereka nantinya. Sehingga, mereka juga akan merasa yakin untuk mampu melakukan hal yang sama dalam proses pengasuhan, begitu juga sebaliknya.

Selanjutnya, hasil penelitian menunjukkan bahwa disiplin merupakan domain yang paling bermasalah bagi setiap informan terkait dengan efikasi diri mereka. Keseluruhan informan menyampaikan bahwa mereka merasa tidak mampu untuk menerapkan rutinitas, menegakkan aturan, dan memperbaiki perilaku anak. Ketidakyakinan orang tua juga dapat 
dilihat melalui cara yang mereka gunakan untuk menegakkan disiplin pada anak, dimana sebagian besar cenderung menggunakan cara yang keras, seperti membentak, menghukum, dan memukul. Hal ini sesuai dengan yang dinyatakan Coleman dan Karraker (2000) bahwa salah satu ciri orang tua dengan parenting self efficacy yang rendah adalah merasa tidak berdaya dalam menjalankan perannya sebagai orang tua dan mendisiplinkan anak dengan cara yang cenderung menghukum. Cara ini digunakan orang tua untuk mendisiplinkan anak juga dikarenakan minimnya pengetahuan mereka terkait cara-cara yang efektif untuk menghadapi perilaku anak yang bermasalah.

Domain disiplin memang merupakan salah satu isu pengasuhan utama yang dihadapi oleh orang tua dari anak usia kanak-kanak madya pada umumnya (Papalia dkk., 2009). Begitu juga bagi orang tua dengan keterbatasan fisik, seperti orang tua tunanetra. Sebagaimana yang ditunjukkan oleh hasil penelitian Prilleitensky (2004) terhadap orang tua dari dua kelompok anak berusia di bawah dan di atas 8 tahun, bahwa keterbatasan fisik tersebut dapat mempengaruhi secara langsung terhadap kemampuan mereka dalam mendisiplinkan anak dan cara yang mereka pilih dalam mengatur perilaku anak. Selain itu, Prilleitensky juga menambahkan bahwa kurangnya dukungan dalam mengakkan disiplin juga menambah kesulitan orang tua. Hal inilah yang terlihat pada informan satu dan dua yang menunjukkan perbedaan dalam bagaimana mendisiplinkan anak, seperti ketika informan satu melarang anak untuk bolos, informan dua hanya membiarkan saja. Tidak adanya dukungan dari pasangan ini menambah ketidakyakinan informan satu dalam melakukan pengasuhan pada domain disiplin.

Selanjutnya, keempat informan dalam penelitian ini menyatakan bahwa keterbatasan penglihatan mereka menjadi salah satu penghalang mereka dalam mendisiplinkan anak, dimana anak sering memanfaatkan kondisi mereka untuk melanggar aturan yang telah diberikan. Sebagaimana yang disampakian oleh Socha dan Staten (2005) bahwa anak dari orang tua tunanetra sering mengambil kesempatan dari kondisi tersebut dan menunjukkan berbagai perilaku negatif di hadapan orang tuanya. Untuk itu, pemberian informasi terkait teknik yang tepat untuk menghadapi perilaku negatif dari anak perlu dilakukan supaya orang tua dapat menghadapi dan menangani permasalahan perilaku tersebut dengan efektif.

Pada domain rekreasi, keempat informan juga merasa tidak yakin bahwa mereka mampu menjalankan tugas pengasuhannya. Sulitnya orang tua tunanetra untuk memfasilitasi kegiatan rekreasi juga disampaikan oleh Deshen (2012). Deshen menyatakan bahwa orang tua tunanetra sulit melakukan kegiatan fisik bersama anak, seperti: bertamasya, berkemah, atau sekedar berkeliling kota. Kesulitan ini umumnya disebabkan oleh sulitnya mobilitas dan pengawasan terhadap anak. Oleh karena itu, sebagian besar dari mereka tidak dapat melibatkan diri dalam kegiatan rekreasi bersama anak, baik sekedar bermain dengan anak di 
rumah maupun mengajak anak untuk pergi ke tempat wisata. Kegiatan rekreasi hanya dilakukan apabila ada bantuan dari keluarga besar, seperti saat keluarga datang berkunjung.

Berikutnya adalah domain prestasi dari parenting self efficacy orang tua tunanetra. Orang tua tunanetra masih dihadapkan dengan kesulitan ketika harus mengajari anaknya secara langsung, khususnya informan satu, dua, dan tiga. Oleh karena itu, orang tua tunanetra menyiasatinya dengan cara menghadirkan guru les atau pun mengantarkan anak mereka ke rumah tetangga untuk belajar. Kurangnya keyakinan informan dapat dipengaruhi oleh keterbatasan penglihatan mereka. Hal tersebut sesuai dengan pernyataan Meadow-Orlans (2002) bahwa orang tua tunanetra akan dihadapkan pada kesulitan saat membantu dan mengajarkan anak mengenai tugas-tugas sekolahnya.

Akan tetapi, keterbatasan penglihatan tidak menjadi alasan bagi informan empat untuk meragukan kemampuannya melakukan pengasuhan di domain prestasi. Berbeda dari ketiga informan yang telah mengalami kebutaan semenjak kecil, informan empat mengalami kebutaan ketika sudah memasuki masa dewasa. Ia juga pernah bersekolah walaupun hanya sampai tingkat SD. Oleh karena itu, ia merasa lebih yakin dalam melakukan pengasuhan pada domain prestasi. Hal tersebut sejalan dengan pernyataan Campion (2005) yang menyatakan bahwa usia orang tua saat menjadi tunanetra dapat mempengaruhi persepsi dan penilaian orang tua terhadap diri sendiri. Informan empat yang mengalami kebutaan saat masa dewasa merasa bahwa pengalamannya sebelum menjadi tunanetra di bidang akademis dapat diterapkan kepada anak.

Lebih lanjut, informan satu dan dua merasa tidak yakin bahwa mereka bisa membantu anak ketika belajar. Mereka juga tidak yakin bisa memfasilitasi berbagai kebutuhan anak dalam bidang pendidikan. Ketidakyakinan informan satu dan dua dipengaruhi oleh anak pertamanya yang sudah tinggal kelas sebanyak dua kali. Hal tersebut sesuai dengan hasil penelitian Freedman-Doan, Arbreton, dan Eccles (1995) bahwa parenting self efficacy orang tua akan menurun ketika anaknya dinilai sebagai murid yang tidak baik oleh guru ataupun pihak sekolah. Sehingga, ketika mereka menyaksikan anak mereka sudah tinggal kelas sebanyak dua kali berturutturut, mereka menjadi ragu atas kemamuan mereka dalam membimbing keberhasilan akademis anak.

Pada domain kesehatan, keempat informan merasakan keyakinan yang berbeda mengenai kemampuan mereka untuk menjaga kesehatan anak. Informan satu dan dua memiliki anak yang terkena penyakit parah, mereka terlihat merasa tidak yakin dapat menjaga kesehatan anak dengan baik. Akan tetapi, anak dari informan tiga dan empat yang hanya tersekena penyakit ringan, seperi flu dan demam, merasa mampu untuk menjaga kesehatan anak. Ketidakyakinan informan satu dan dua yang memiliki anak sakit parah tersebut dapat dijelaskan berdasarkan pernyataan Cram, Waarfield, dan Krauss (2001) bahwa orang tua yang memiliki anak yang sakit parah akan mengalami permasalahan dalam 
menjalankan peran dan tugas pengasuhannya. Kesulitan dalam menjalankan peran tersebut akan lebih dirasakan oleh orang tua tunanetra karena mereka juga mempunyai keterbatasan pada diri mereka sendiri.

Berdasarkan hasil penelitian, pemaknaan orang tua terhadap keterbatasan penglihatan mereka juga terlihat dapat menjadi faktor yang mempengaruhi parenting self efficacy. Ketika orang tua memandang keterbatasan penglihatan sebagai hambatan dalam melaksanakan tugas pengasuhan, maka mereka akan merasakan banyak kesulitan. Hal itu sesuai dengan pernyataan Hurlock (1980), bahwa individu yang tidak menerima kondisi keterbatasannya, tidak akan mampu berpikir logis tentang baik buruknya masalah yang sedang dihadapi, sehingga dapat menimbulkan perasaan tidak mampu dan rendah diri.

Lehih lanjut, orang tua tunanetra masih dihadapkan dengan pandangan negatif dari masyarakat maupun keluarga. Ketika menghadapi keraguan sebagai umpan balik dari pengasuhan mereka, maka terlihat bahwa mereka menginternalisasikan keraguan tersebut pada pengasuhan yang mereka lakukan. Faktor budaya dan komunitas tempat tinggal yang tidak mendukung, dapat mendorong munculnya rasa keraguan diri dalam menjalankan pengasuhan

Faktor pengetahuan dan pendidikan orang tua juga dapat mempengaruhi parenting self efficacy. Keempat informan memiliki pengetahuan yang terbatas mengenai pengasuhan. Kurangnya pengetahuan membuat mereka merasa tidak yakin dan kebingungan pada saat melakukan pengasuhan, terutama dalam domain disiplin, prestasi, dan kesehatan. Hal tersebut sejalan dengan yang disampaikan oleh Meadow-Orlans (2002) bahwa orang tua tunanetra mengalami kesulitan untuk mendapatkan akses informasi mengenai pengasuhan yang baik. Untuk itu, pemberian informasi dan penyuluhan berkala yang diberikan kepada orangtua tunanetra terkait pengasuhan anak sangat diperlukan untuk menujang kualitas pengasuhannya.

Pengalaman langsung orang tua dengan anak merupakan faktor lain yang dapat mempengaruhi dengan parenting self efficacy. Informan satu dan dua tidak pernah mengasuh dan merawat anak sebelumnya, sedangkan informan tiga dan empat sering membantu orang terdekatnya mengasuh anak. Hal tersebut membuat informan satu dan dua merasa kebingungan saat pertama kali mengurus anak mereka, sedangkan informan tiga dan empat merasa sudah tidak begitu kesulitan. Hal tersebut sejalan dengan pernyataan Coleman dan Karraker (2005), bahwa pengalaman langsung orang tua menghadapi anak tersebut dapat menjadi sumber informasi yang penting dalam pembentukan self efficacy seseorang.

Di samping itu, kesibukan bekerja juga mempengaruhi keyakinan orang tua tunanetra. Hal itu ditemukan pada informan satu dan empat. Ketika mereka disibukkan dengan pekerjaan, maka waktu yang bisa diluangkan untuk anak semakin terbatas. Hal tersebut sesuai dengan pernyataan Eccles dan Harold (dalam Hoover-Dempsey \& Sandler, 1997) bahwa kurangnya keterlibatan orang tua dalam 
berbagai kegiatan bersama anak, dapat menurunkan parenting self efficacy.

Selanjutnya, berdasarkan analisis yang dilakukan pada keempat informan, bisa dilihat bahwa informan satu dan dua lebih merasa tidak yakin dalam melaksanakan pengasuhan dibandingkan dengan informan tiga dan empat. Walaupun mereka sama-sama orang tua tunanetra, tetapi ada beberapa faktor lain yang membedakan keluarga tersebut. Salah satunya adalah faktor ekonomi.

Berdasarkan data yang ada, dapat dilihat bahwa orang tua tunanetra dengan penghasilan yang rendah cenderung mengalami ketegangan psikologis disebabkan oleh tidak bisanya memenuhi berbagai kebutuhan rumah tangga. Ketika mereka merasa kesulitan dan tidak mampu menyediakan berbagai kebutuhan, kesempatan, dan pengalaman bagi anak, maka perasaan tidak yakin pun akan muncul. Hal di atas sejalan dengan pernyataan Coleman dan Karraker (2000) yang menyatakan bahwa kondisi ekonomi dapat mempengaruhi parenting self efficacy seseorang.

Faktor selanjutnya adalah jumlah anak yang dimiliki oleh orang tua tunanetra. Informan tiga dan empat merasa lebih yakin karena mereka hanya memiliki satu orang anak. Mereka memang sengaja membatasi jumlah anak dengan menggunakan KB. Hal tersebut dapat dijelaskan melalui hasil penelitian Holloway dan Behrens (2002) yang menunjukkan bahwa parenting self efficacy ibu dengan satu anak lebih tinggi dibandingkan dengan ibu yang memiliki anak lebih banyak. Orang tua yang memiliki banyak anak akan membutuhkan waktu, tenaga, dan biaya melebihi orang tua dengan satu anak dalam melakukan pengasuhan.

Faktor berikutnya adalah dukungan sosial. Informan satu dan dua mendapatkan bantuan dari adik angkatnya dalam melakukan pengasuhan, sedangkan informan tiga dan empat tidak mendapatkan bantuan apa-apa. Akan tetapi, informan satu dan dua tetap merasa tidak yakin bahwa mereka bisa menjalankan tugas pengasuhan dengan baik. Hal tersebut tidak sejalan dengan hasil penelitian Teti dan Gelfand (1991) bahwa dukungan dari pihak lain saat melakukan pengasuhan dapat meningkatkan parenting self efficacy. Hal itu bisa terjadi karena kurangnya pengetahuan adik angkatnya tersebut tentang pengasuhan anak. Sebagaimana disampaikan oleh Wiryasaputra (2003), bahwa dukungan sosial tidak dilihat dari jumlah atau frekuensinya, melainkan dari mutu atau kualitasnya. Oleh karena itu, kehadiran adik angkat yang memiliki pengetahuan terbatas terkait pengasuhan tersebut tidak banyak membantu dalam menjalankan proses pengasuhan.

Berdasarkan uraian di atas dapat dilihat bahwa sama halnya dengan parenting self efficacy pada orang tua tunarungu (Antawati \& Murdiyani, 2013), parenting self efficacy pada orang tua tunanetra juga dipengaruhi oleh keterbatasan dan ketersedian dukungan selama pengasuhan. Akan tetapi, penelitian ini menunjukkan pentingnya kualitas dukungan yang diberikan daripada kuantitasnya, seperti tingkat pengetahuan 
yang dimiliki oleh pemberi dukungan tersebut selama proses pengasuhan. Selain itu, keterbatasan orang tua bukanlah penentu utama dari parenting self efficacy, melainkan tergantung pada bagaimana cara orang tua tersebut memaknai keterbatasannya. Beberapa faktor lain yang juga ditemukan dapat mempengaruhi parenting self efficacy orang tua tunanetra adalah kondisi ekonomi keluarga, jumlah anak, serta kesibukan bekerja. Sementara, faktor yang berasal dari diri orang tua adalah persepsi terhadap pengalaman masa kecil, pengetahuan terkait pengasuhan, usia mengalami kebutaan, serta pengalaman mereka dengan anak-anak.

Hasil penelitian ini juga menunjukkan bahwa keyakinan diri orang tua dapat mempengaruhi perilaku pengasuhan. Informan satu dan dua cenderung tidak yakin dibandingkan informan tiga dan empat. Pada saat menjalankan pengasuhan mereka lebih fokus pada kesulitan. Mereka juga cenderung merasa tidak berdaya, pasrah, dan tidak berusaha mencari jalan keluar. Berbeda dengan informan satu dan dua, informan tiga dan empat tidak terlalu menyinggung kesulitan dalam pengasuhan. Mereka juga selalu berusaha agar kebutuhan anaknya terpenuhi dengan baik. Hal tersebut sesuai dengan pernyataan Jones dan Prinz (2005) bahwa parenting self efficacy merupakan variabel transaksional dimana orang tua yang memiliki keyakinan diri akan memperoleh kepuasan dari perilaku pengasuhan mereka. Kepuasan itu akan mengarah pada perilaku pengasuhan yang positif dan akan meningkatkan kecenderungan untuk menghasilkan perilaku anak yang juga positif.

\section{Kesimpulan}

Berdasarkan hasil penelitian diperoleh gambaran bahwa orang tua tunanetra yang memiliki anak usia kanakkanak madya cenderung memiliki keyakinan yang lebih ketika melaksanakan pengasuhan pada domain nurturance. Mereka merasa mampu untuk memberikan dukungan emosional kepada anak dan memiliki kesadaran terhadap perasaan anak. Akan tetapi, mereka cenderung merasa tidak yakin pada domain disiplin dan rekreasi. Sementara itu, keyakinan mereka cenderung bervariasi dalam menjalankan pengasuhan pada domain prestasi dan kesehatan.

Keragaman keyakinan mereka tersebut dipengaruhi oleh pemaknaan mereka terhadap keterbatasan penglihatan, pengalaman masa kecil, dan perlakuan dari masyarakat sekitar, pengetahuan, dukungan dari pasangan, kondisi anak yang sehat, penghasilan yang cukup, waktu bekerja yang senggang, pengalaman yang banyak dengan anak-anak, serta persepsi yang positif terhadap jumlah anak. Lebih jauh, penelitian ini juga menunjukan bahwa orang tua yang keyakinan pengasuhan yang lebih baik, mereka cenderung memiliki emosi dan perilaku positif.

\section{Daftar Pustaka}

Antawati, D.I., \& Muridyani, H. (2013). Parenting self efficacy dalam kaitannya dengan perilaku pengasuhan pada orang tua tunarungu dengan anak berpendengaran normal. Surabaya: Universitas Muhammadiyah Surabaya. 
Bandura, A. (1989). Regulation of cognitive processes through perceived self-efficacy. Developmental Psychology, 25 (5), 729-735.

Bowlby, J. (1980). Attachment and loss: Vol 3. Loss: Sadness and depression. London: Hogarth Press.

Brooks, J. (2011). The process of parenting ( $8^{\text {th }}$ edition). New York: McGraw- Hill.

Campion, M.J. (2005). Who's fit to be parent? United States: Routledge.

Coleman, P.K., \& Karraker, K.H. (1997). Self-efficacy and parenting quality: Finding and future applications. Developmental Review, 18, 47-85.

Coleman, P.K., \& Karraker, K. H. (2000.) Parenting self-efficacy among mothers of school-age children: Conseptualization, measurement and correlates. Family Relations: An Interdisciplinary Journal of Applied Family Studies, 49 (1), 13-24.

Coleman, P.K., \& Karraker, K.H. (2005). Parenting self-efficacy, competence in parenting, and possible links to young hildren's social and academic outcomes. Dalam Saracho, O.N., \& Spodek, Bernard (Ed). Contemporery perspectives on families, communities, and schools for young children. United States: IAP.

Cram, P.H., Waarfield, M.E., Shonkoff, J.P., \& Krauss, M.W. (2001). Children with disabilities: A longitudinal study of child development and parent well being. Monographs of the society for research in child development, 66 (3).

Deshen, S. (2012). Blind people: The private and public life of sightless israelis. New York: SUNY Press.

Freedman-Doan, C.R., Arbreton, A.J., \& Eccles, J.S. (1995). Under my Influence? Parent and family factors associated with parenting efficacy in the elementary years. Symposium: Models of parenting efficacy from infancy through adolescence.

Glover-Graf. (2012). Sexuality and disability. Dalam Marini, Iromo dkk (Ed). Psychosocial aspects of disability: Insider perspective and strategies for counselors. New York: Springer Publishing Company.

Hallahan, D,P., \& Kauffman, J.M. (1988). Exceptional children: Introduction to special education ( $4^{\text {th }} e d$ ). New Jersey: Prentice Hall.

Holloway, S.D., \& Behrens, K.Y. (2002). Parenting self efficacy among Japanese mpthers: Qualitaive and quantitative perspective on its association with childhood memories of family relations. New Diractions for Child and Adoloescent Development, 96, 27-43.

Hong, Y. R., \& Park, J. S. (2012). Impact of attachment, temperament, and parenting on human development. Korean Journal of Pediatrics, 55(12), 449-454.

Hoover-Dempsey, K.V., \& Sandler, H. M. (1997). Why do parents become involved in their children's edication? Review of educational research, 67 (1), 3-42.

Hurlock, E.B. (1980). Psikologi perkembangan suatu pendekatan sepanjang rentang kehidupan. Jakarta: Erlangga.

Jones, T., \& Printz, R. (2005). Potential roles of parental self-efficacy in parent and child adjusment: A Review. Clinical Psychology Review, 25 (3), 341-363.

Kef, S., \& Hatzmann, J. (2011). Parenting of mothers and fathers with low vision. Amsterdam: VU University.

Leerkes, E. M., \& Crockenberg, S. C. (2002). The development of maternal self-efficacy and its impact on maternal behavior. Infacy, $3(2), 227-247$. 
Meadow-Orlans, K.P. (2002). Parenting with a sensory or physical sisability. Dalam Bornstein, M.H(Ed). Handbook of parenting, 4. New Jersey: Lawrence Erlbaum.

Moleong, L.J. (2007). Metodologi penelitan kualitatif. Bandung: PT Remaja Rosdakarya Ofset.

Papalia, D., Olds, S., \& Feldman, R. (2009). Human Development "Perkembangan Manusia" (Edisi 10). Jakarta: Salemba Humanika.

Prilleltensky, O. (2007). My child is not my carer: Mother with physical disabilities and the well-being of children. Dalam Marini, I., \& Stebnic, M.A (Ed). The Psychological and Social Impact of Illness and Disability $\left(6^{\text {th }}\right.$ edition). New York: Springer Publishing Company.

Putri, A.A. (2012). Bekerja dalam keterbatasan. Majalah Psikomedia: Media Bicara dan Perilaku (Edisi Tahun 2012).
Socha, T.J., \& Staten, C. (2005). Parenting by touch, sound and scent I: Towards a positive eserch agenda. Parental Communication and Blindness.Boston: National Communication Association.

Suzuki, S., Holloway, S. D., Yamamoto, Y., \& Mindnich, J. D. (2009). Parenting selfefficacy and social support in Japan and the United States. Journal of Family Issues, 30(11), 1505-1526.

Teti, D.M., \& Gelfand, D.M. (1991). Behavioral competence among mothers of infant in the first years: The meditational role of maternal self efficacy. Child Development, 62 (5), 918-929.

Wiryasaputra, T.S. (2003). Mengapa berduka, kreatif mengelola perasaan duka. Yogyakarta: Kanisius. 